\title{
Analysis of Food Policy: A Study of Malaysia
}

\author{
${ }^{1}$ Rasheed Mohamed Kutty and ${ }^{2}$ Mohammad Javad Nekooei \\ ${ }^{1}$ Universiti Teknologi Malaysia ,Kuala Lumpur, Malaysia \\ ${ }^{2}$ Department of Mechanical Engineering, Safashahr Branch,Islamic Azad University, Safashahr, Iran
}

\begin{abstract}
Agricultural sector has been a taproot for the development of Malaysian economic since before Independence period. This sector has also play a vital role which is very important in the Malaysian social and economic development. Agricultural commodities such as rubber, palm oil have contributed the bigger role for the success in agricultural sector. In the year of 1960 agricultural sector contribution for the Gross Domestic Product (GDP) is about 40\% (percent) and in the year of 2005 the contribution from this sector to the Malaysian GDP is only about 7.2\% (percent). Starting from the year of 1987 (Amriah 2006:50), production sector has exceed the agricultural sector in term of contribution to the GDP, employment opportunities and export income effected from the industrialization encouragement policy. This situation is the clear picture to show that the agricultural sector was not a catalyst to the Malaysian economic and basically this bring us to understand that the industrialization sector actually is the catalyst to the Malaysian economic now days.
\end{abstract}

Keywords: Food, Policy, Agricultural, Malaysia

\section{Introduction}

However, agricultural sector still define/known as important and strategic to the Malaysian economic. Agricultural still been important economics activities even though Malaysia currently has change to the industrialization country. According to Zulkifli Senteri (1997: 24) agricultural sector still plays vital role to the development of industrialization sector. The bigger part from the economic expand in develop countries such as Europe and USA begins with agricultural sector but due to the time circulation emphasize in country economy will change whether it is planned, forced or evolution. According to Abdul Khaled Ibrahim (1998: 55), even in countries such as USA and Japan the industrialization sector is the most important (foremost) but these countries still emphasize on agriculture sector by contributing large amount of public expense to this sector.

In order to cure/restore and gives new dimension to the agriculture sector, government has implemented few plans and policy as to make this sector continuously relevant to reference source and pathway to Malaysian Agricultural sector in the future. According to Ahmad Atory Hussien (1992:1) public policy in this country has been created from political process and literally this public policy is whatever policy or projects, programs, plans or any suggestions from the government. In doing review on policy which is related with country food, the writer has reviewed data from the year of 1957 to year 2006 that are since the country achieved independence till initial launching of 9th. Malaysian Plan. In doing analysis on food policy, the writer has divided it into two parts. First is plan, program, project or campaign which has been done specially to increase country food production. Among others are:

i. $\quad$ Green Book Plans, $1^{\text {st }}$. Phase 1974

ii. Green Book Plans, $2^{\text {nd }}$. Phase 1976

iii. Redevelopment of Green Book Plans 1983

iv. Green Earth Campaign 2005

v. Permanent Garden Project For Food Production 2001

vi. Kluang, Modern Agriculture Project 2004

Secondly, country agriculture policy which is indirectly will touch on the importance of agriculture to the country as a whole per below:

i. 1st. Country Agricultural Policy 1984

ii. $2^{\text {nd }}$. Country Agricultural Policy $1992-1997$

iii. $3^{\text {rd }}$. Country Agricultural Policy $1998-2010$ 
Green Book Plan, Green Earth campaign and all agricultural programs has directly focused to production of food item in this country and has encouraged the pupils to involve and took part in the activities related to the agriculture. Besides that, Country Agricultural Policy has been collectively focusing on the development and expands on agricultural sector in Malaysia. The existence of this policy and all the plans which are related to agriculture sector has brought a paradigm shift to the country economic and social situation. The concern in succeed on these kind of programs has open many eyes whether they are government, private sector or pupil in the country to understand that the importance of agriculture sector should be defend in order to protect safety and happiness of all parties.

Agriculture Sector in Malaysia generally can be divided into two big categories which are food product group (rice, livestock, vegetables, fruits and fisheries) and Industry Plants/Crop Group (palm oil, rubber, forestry and others). In the chapter the writer has do an analysis on Green Earth Plan, programmed and campaign which has been implemented together with Country $1^{\text {st }} .2^{\text {nd }}$. and $3^{\text {rd }}$. Agriculture Policy only from the point of commodities or food product with greater emphasize given to Paddy Industry and country rice. Paddy industry and rice then will be review in detail because this sector is the most important as it provide food basis to the pupils. Besides that, the government has also recognized it as measurement base to define the country food security condition.

\section{Comparison Analysis For Green Book Plan (GBP), Green Earth Campaign (GEC), Permanent Garden For Agricultural Production And Kluang Modern Agriculture Project}

The setup of GBP and GEC by the government basically is to increase country food production and to guarantee that food stock/item is adequate for people with reasonable price. The implementation of GBP and GEC are also indirectly shows to us that our country facing problem in food production. If it is not true, we should ask back the reason for one plan or campaign to encourage people to plants and this effort was boost as whole at national level. Generally all this plans and campaign are one policy which is very good to country and people. Nobody or any party can deny or reject the reasonableness of this action which brings good to every people in Malaysia. But, until now we should be asking question on where the GBP phase one, two and three which has are bring success to our country and how the acceptance level of this policy from the people. Why after 31 years the government want to activate the GEC.

GBP was firstly initiated by Tun Abdul Razak in 1974 and followed by GBP phase two in Tun Hussien Onn period in 1976 and the third in 1983 in Tun Dr. Mahathir Mohamed era which has nearly same reason for the setup and implementation. The establishment of these three GBP has close relationship to current issue which dominates the country at that time. The writer in this thesis identifies initial idea for the establishment of GBP by Tun Abdul Razak came from political environment condition which occurs in or outside the country at that time. So, situation has actually forced for the initiation of this idea and it is not something spontaneous or solely done to increase the country food stock. Next the establishment of GBP phase two and three are the continuation from it and few issues and events which happened that time are very relevant for the GBP to be continuously maintain. Besides that, what really interesting after 31 years the governments come again with GEC to replace GBP. Campaign if compared with plan will surely would not a big policy same as per GBP in Tun Abdul Razak period. Other than that, GBP changed to GEC according to time which earth should be greened with plants. However, the existence of GEC is also has it own reason on why the government launched this campaign. Table 1 below shows in detail on why GBP and GEC are implemented by government.

Table 1: Analysis On The Establishment Of GBP and GEC

\begin{tabular}{|c|c|c|c|}
\hline GBP & Period & Year & Reason For The Establishment \\
\hline $\begin{array}{l}\text { Phase } \\
\text { One }\end{array}$ & $\begin{array}{ll}\text { Tun } & \text { Abdul } \\
\text { Razak } & \end{array}$ & 1974 & $\begin{array}{l}\text { i. Country during that time faced with very bad inflation and effect } \\
\text { the economy. } \\
\text { ii. These were due to the increased in price of goods from outside } \\
\text { (imported inflation) and it caused price of goods in the } \\
\text { country increased. } \\
\text { iii. The inflation problem and decreased in economy not only } \\
\text { occurred in Malaysia but happened in the whole world at } \\
\text { that period of time which caused the increased in price of } \\
\text { food products. } \\
\text { iv. To overcome this problem country must ready to produce its own } \\
\text { product internally without depending upon outside country. } \\
\text { v. Scarcity Demonstration Event by student in Baling Kedah. } \\
\text { vi. Emergence of "Green Revolution" in } 1960 \text { where these } \\
\text { revolution occur due to the food shortage at world level and } \\
\text { the need for change from agriculture technology with yield }\end{array}$ \\
\hline
\end{tabular}




\begin{tabular}{|c|c|c|c|}
\hline & & & $\begin{array}{l}\text { of heredity, seeds and agriculture technology which was } \\
\text { more sophisticated. } \\
\text { vii. World Food Crisis in } 1974 \text { where demand for food has increased } \\
\text { and it caused deficient of stock of food, price increased very } \\
\text { high and competition occurred within country to get food } \\
\text { stock. }\end{array}$ \\
\hline $\begin{array}{l}\text { Phase } \\
\text { Two }\end{array}$ & $\begin{array}{l}\text { Tun Hussien } \\
\text { Onn }\end{array}$ & 1976 & $\begin{array}{l}\text { i. Continuation idea from Tun Abdul Razak to overcome weakness } \\
\text { in GEC at phases one. } \\
\text { ii. Country still in inflation situation } \\
\text { iii. Continuously encouraging cultivation and farming within house } \\
\text { surrounding for family usage. } \\
\text { iv. The success of GEC phase one for Tun Hussein Onn proved with } \\
\text { the low of current food price and inflation begin to reduce } \\
\text { compared to food price in West Country. }\end{array}$ \\
\hline $\begin{array}{l}\text { Phase } \\
\text { Three }\end{array}$ & $\begin{array}{ll}\text { Tun } & \text { Dr. } \\
\text { Mahathir } & \\
\text { Mohamed } & \\
\end{array}$ & 1983 & $\begin{array}{l}\text { i. Country was on inflation due to world economy depression. } \\
\text { ii. Initial GEC described as effective and due to that government } \\
\text { thought the activities should be continuously done. }\end{array}$ \\
\hline GEC & $\begin{array}{ll}\text { Datuk } & \text { Seri } \\
\text { Abdullah } & \\
\text { Badawi } & \end{array}$ & 2005 & $\begin{array}{l}\text { i. This program was not called as plan but changed to campaign } \\
\text { and the pronounce changed from book to earth so it is easier } \\
\text { to understand by the pupils. } \\
\text { ii. The emergence of GEC was based on cultivation practice among } \\
\text { pupils. } \\
\text { iii. For the government the approach for reintroduction of this } \\
\text { campaign was actually consequence from increased in oil } \\
\text { price at world market. }\end{array}$ \\
\hline
\end{tabular}

From the above tables, GBP and GEC were launched by the government based on current situation which happened in the country or world. Food program in the country was not done consistently but occasionally. The truth is that plan and campaign to develop the country agriculture sector mostly food sector cannot be denied of its importance.

Even, this movement should always be practiced so that it was not just taken for granted or not seriously done. We implement certain plan just because it relate to current problem and not focusing on long term factor. Even though many people blamed slumped in country agriculture sector is due to the country industrialization but the truth is pupils and policy doer has forgotten food are main source which is important to human living and it should not be produced occasionally. Human need food for their living and so that policy implementation related to food should be consistent and given new dimension/ breath in order to prestige agriculture sector which is more arranged. If only GEC succeed, now, country which is in 2005 may not import food from outside which valued more than RM17.8 billion (Utusan Malaysia 22 November 2006:2). Touching on GEC, it is just begin since 2006 and the impact still not seen or feel.

\section{$1^{\text {st. }}$ Malaysian Agriculture Policy 1984}

\section{Malaysian Agriculture Policy}

Country Agriculture Policy (MAP) which was launched by Deputy Prime Minister of Malaysia, Dato' Musa Hitam as Chairman of Cabinet Committee related to MAP on 12 January 1984 ( Malaysia, Ministry of Information 1992: 18) Why MAP was launched. According to 1984 MAP document this policy was develop to guarantee development rate of agriculture sector are stable and continuous compared with others sector in the economy. MAP also present guidelines for agriculture development until year 2000, lay down key role of this sector in the economy and obstacles faced also strategies which will be uses (Ministry of Agriculture 1984: 1). Besides that, MAP also was developed as guidelines to help/assist government and private sector to activate agriculture sector (consist of small crop sector, farming, fisheries and forestry) and then the whole country economy (Ministry of Information 1992: 18). For Dato' Musa Hitam presentation of MAP was solely to give guidelines for all the planner, doers, and administrator in the public and private sector. What most important is, this policy has described to the pupils on opportunity for them to get involve in agriculture and spread the income to come out from poorness.

According to him, agriculture are the biggest sector and important for country economy. Due to that the development of this sector need one long term policy which is comprehensive and sensitive to current and future country need (Ministry of Information $1984: 8$ ). According to interim review on $4^{\text {th }}$. Malaysian Plan $1981-$ 1985 (1984: 272), MAP was developed based on role that should be played by the agriculture sector in the development of country where this policy will give attention to all the effort to reduce poor and also at the same time maintained agriculture sector contribution to the country. According to $3^{\text {rd }}$. Country Agriculture Policy 
1998 -2010 (1998: 5) CAP 1984, the purpose was to liberalize agriculture sector phase by phase and was implemented since early 1980's.

According to Jomo (1988: 71) final draft of Malaysian Agriculture Policy was expelled/discharged/ produced by government was written by the Prime Minister himself, Datuk Seri Dr. Mahathir Mohamad. Such awaited policy for a long time only has 13 pages and the contents not that detail. This policy then has been detailed out when $4^{\text {th }}$. Malaysia Interim/Half Year Plan Review was produced. Jomo thought, MAP was actually a policy which answer all critics which expelled/discharged by the World Bank in 1983 for Malaysia Agriculture Sector which start to reduced in one document with the title "Considerations For A National Agricultural Policy". Where World Bank critic Malaysia because of excessive investment in rice sector, slow expand in small farmer merging, bureaucracy problem and inconsistent policy (Jomo 1988: 71).

\section{$2^{\text {nd }}$. Malaysian Agriculture Policy $1992-1997$}

Revised Country Agriculture Plan (MAP) consist a period of 1992 - 1997. This policy was legislating by one study which was done by High Committee Review on Country Agriculture Policy in 1989 which was chaired by Deputy Prime Minister during that period, En. Abdul Ghafar Baba. Revision on previous/old MAP was done to make sure that agriculture sector able to do quick changes and applicable to rapid changes to economic base whether in or outside the country. Test checked also should be done to increase agriculture sector contribution for the growth and development of the country as a whole. Besides that, MAP also give more emphasize to overcome productivity issues, efficiency, competitiveness in the context of pure development and chain/relation with other economics. This policy also outline moderate and long term strategy to add and broaden production of food, increase role of private sector, rearrange marketing and fasten the industry development based on agriculture (Ministry of Agriculture 1998: 5). MAP for the period 1992 - 1997 also merged development philosophy and way for agriculture sector as contain in 2nd Long Term Draft Plan and Mission 2020 (INTAN 1994: 31 - 33).

This MAP 1992 - 2010 are more detail and arranged where it contain 81 pages compared to MAP 1984 which was not thorough and only contain 14 pages.

\section{$3^{\text {rd }}$. Malaysian Agriculture Policy}

$3^{\text {rd }}$. Country Agriculture Policy $1998-2010$ to replace $2^{\text {nd }}$ MAP $1992-1997$ was done for six years only. $3^{\text {rd }}$. CAP which is more comprehensive and overall if compared with the previous one. These was clear that the first MAP which was only 14 pages and increased to 81 pages in second MAP and further in third MAP the content increased to 295 pages. For first time the third MAP make involved Ministry of Industry ( Perusahaan Utama) in making a plan on agriculture policy where farming commodity and forestry field is the responsibility of that Ministry. Why such a new policy was design while old policy still going on for about six years and will surely difficult to define it achievement in a short period of time.

Based on $3^{\text {rd }}$. MAP $1998-2010$ ( $\left.1998: 3-9\right)$ report, changes in economic structure has emerged issues and new challenges for agriculture sector and forestry where it generate labor constraint forced, limited agriculture land and continuous increased in production due to competition among sector and competition at international market because of commerce liberalization. Financial crisis effected the country in 1997 due to liberalization in financial market which caused financial market exposed to speculation's Inconsistency and deterioration in exchange rate compared to world main currency has spoiled stableness and country stock food security. So that, at this level, it was identified country food stock are easily exposed to outside factor and at this time government thought agriculture sector should be upgrade from continuously depend upon outside food. Lower current exchange rate compared to other world main currency caused serious force onto Malaysia foreign exchange reserve. The impact from this, in 1997 we saw commerce of food item excluding palm oil has experienced deficit amounted to RM4.74 billion or 49\% (percent) are from current account deficit for product and services. Influence of foreign exchange rate not only caused deficit increased to 30 percent but reduction in value of Ringgit has also caused drastic increased in agriculture input price and also high inflation pressure on food item. Malaysia foods import billed continue to increase where in 1997, imported food valued to RM10 billion compared to RM4.6 billion in 1990.

\section{Malaysia Food Policy Analysis From 1974 To 2005}

Writer in this section will discuss on policy, plan, project and campaign which have been exercised by the government to increase production of country food stock. From this study also we came to know that country does not have one specific food policy (National Food Policy) in forming a strategy for continuous food production. But Green Book Plan, Green Earth Campaign, Permanent Garden For Food Production, Kluang Modern Agriculture Project and Country Agriculture Policy which were implemented by the government seem to be one policy directive to Country Food Policy. Figures 2 below show the emergence of food policy. Various 
policy are the reason which been a guidelines and measurement basis for the policy doer or policy researcher in valuing country food policy status.

Figures 2: Various Plan, Policy, Project And Campaign Which Form/Shape Country Food Policy

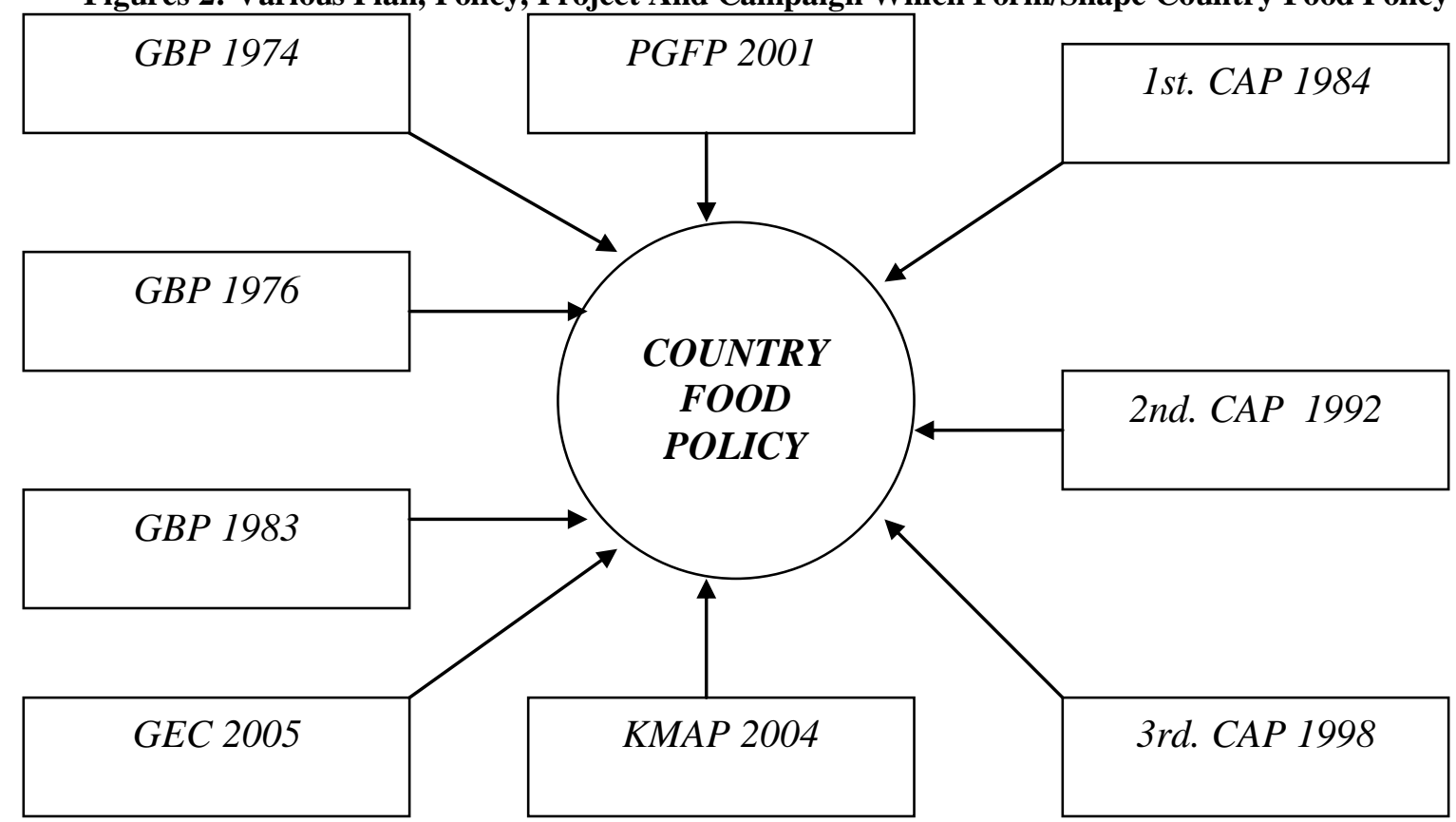

The emergence of country food policy in much form such as plan, policy, project and campaign rises question on why not one long term policy which is holistic be used for long term usage. Thru this study also, most of the government officer agree this reality and all those various and inconsistent policy make them more difficult to exercise daily task/job. This mean even who become Prime Minister, Agriculture Minister or even changes happen in government ruling this food policy should be set as guidelines. Changes can be done to this policy according to the need and when applicable. But, whether the existence of food policy can solved country food problem since Independence Day? Figures 3 show country self sufficiency stage in term of food commodity until year 2005. These were clear to describe country food policy which taproot by various plan, policy, project and campaign not able to produce hundred percent country food stock except for certain food commodity only.

Figures 3 : Shows Achievement Of Country Food Policy From 1974 Until 2005 And Its Achievement Toward Country Food Self Sufficiency In The Year Of 2006
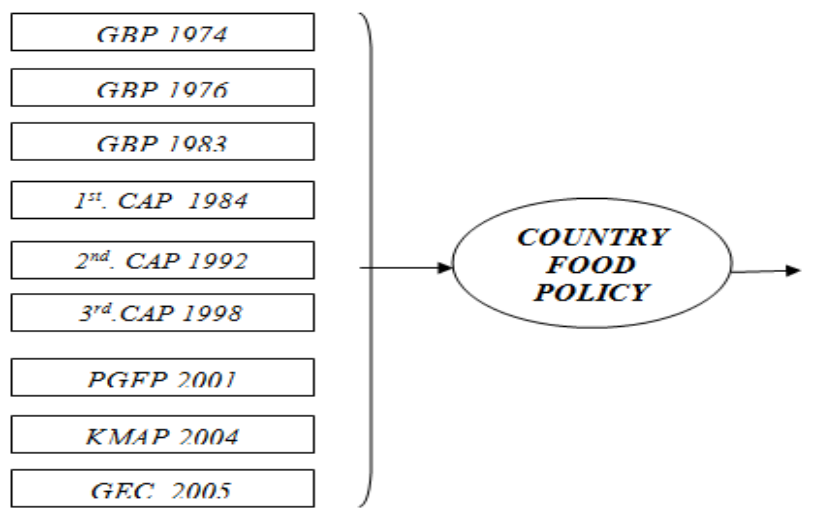

\begin{tabular}{|ll|}
\hline Rice & 72.40 \\
Vegetables & 58.00 \\
Fruits & 114.00 \\
Farming & \\
Meat & 23.10 \\
Lamb & 9.03 \\
Pork & 111.60 \\
Chicken/Duck & 121.20 \\
Poultry & 118.80 \\
Milk & 4.60 \\
Fish Product & 93.00 \\
\hline
\end{tabular}

\section{Conclusion}

The important of agriculture sector to economy and country history are something unique. Country economy which before depend to agriculture as development engine has replaced by manufacturing sector. The important of economy relatively decrease in term of contribution to GDP and employment. Even this sector undergoes reduction in terms of economy but this sector not continuously going thru deterioration period. 
Malaysia Agriculture Sector especially estate/farmstead commodity such as rubber and palm oil continuously plays an important role as country main agriculture export sources. In addition this agriculture sector also becomes a catalyst for production of raw material to fulfill needs in country industrialization sector. Agriculture sector that face with downturn period is food commodity sector where country has to depend mostly from outside food sources to fulfill local need. In this paper, the writer has done an analysis on country food policy since 1974 until year 2005. Malaysia do not have one food policy but writer has take an approach by including all the plan, policy, project and campaign implemented by the government to increase country food stock since the year of 1974 until 2005 as Malaysia Food Policy.

Green Book Plan and Country Food Policy which were introduced since 1970 until now still do not change problem in food sector faced by the country. This does not mean country take for granted food sector but the boost in country development in term of industrialization set aside this activity. Pupils generally are not interested in agriculture activity and even the existence farmer also become older. In addition, decreasing in suitable land for agriculture, unused land, high cost of production, outdated technology and reduction in source of water complicate this situation. Country rice and paddy industry which become back bone to the food security face the same fact. Country still depends on rice from outside due to the policy and internal problem which until today are not consistent.

For writer, actually Malaysia able to produce its own food if everybody put an effort and work together. Besides policy implemented by government, there should be good response from people from all level to prestigious agriculture in Malaysia. Even though the responsibility of farmers are to plant food crop, this does not mean that they themselves responsible for all this deficiency. From the institution of King, government, professional group, support group/layman, graduate, students, workers and cleaners should work together to ensure agriculture sector in Malaysia especially food commodity achieved its target/mission.

\section{Acknowledgements}

The authors gratefully acknowledged to UNIVERSITI TEKNOLOGI MALAYSIA for supporting the research fund under Grant.

\section{References}

[1] Ahmad Hassan Osman, Yap Kim Lian \& Zawiah Chik. 1982. Agricultural policy and program history in Malaysia. Research paper submitted to the Asean Agricultural Planning Centre, September.

[2] Amriah Buang. 2007. Pertanian kecil Melayu dan kelestariannya. Bangi: Penerbit Universiti Kebangsaan Malaysia.

[3] BERNAMA. 2007. Projek pertanian moden Ayer Hitam keluarkan hasil RM 4 juta sebulan. 14 Ogos. http://www.bernama.com/bernama/v3/bm/printable.php?=279175 [2 November 2007].

[4] Chamhuri Siwar, Surtahman Kastin Hassan \& Norshamliza Chamhuri. 2005. Ekonomi Malaysia edisi keenam. Petaling Jaya: Pearson Malaysia Sdn Bhd.

[5] Poorian,Mahmood,mohammad javad nekooei , and Yusof bin boon. "ACADEMIC CHEATING IN HIGHER EDUCATIONTHE EFFECT OF A STUDENT DEVELOPMENT APPROACH A Study at Universiti Teknologi Malaysia." IOSR Journal of Research \& Method in Education (IOSR-JRME),Vol.1, pp.40-3. http://www.iosrjournals.org/iosr-jrme/pages/v1-i6.html.

[6] Chamhuri Siwar. 1988. Isu-isu ekonomi. Kuala lumpur: Dewan Bahasa \& Pustaka.

[7] Chamhuri Siwar, Abd Malik Ismail \& Abdul Hamid Jaafar (pnyt.). 1998. Reformasi pertanian Malaysia kea rah Wawasan 2020. Bangi: Universiti Kebangsaan Malaysia.

[8] Fatimah Mohamed Arshad. 1996. Food security. Dlm Jomo K. S. \& Ng Suew Kiat (pnyt. ). Malaysia’s economic Development policy and reform, hlm. 107-129. Kuala Lumpur: Pelanduk Publications

[9] H. Osman Rani, Jomo K. S \& Ishak Shari (pnyt.). 1981. Development in the eighties with emphasis on Malaysia. Bangi: Universiti Kebangsaan Malaysia.

[10] Kementerian Pertanian dan Industri Asas Tani, Bahagian Industri Tanaman, Ternakan dan Perikanan. 2006. Taman Kekal Pengeluaran Makanan (TKPM). http://agrolink.moa.my/moa/index2.php?option=com_content\&task=view\&id=174\&pop=... [2 November 2007].

[11] Kementerian Pertanian dan Industri Asas Tani, Bahagian Industri Tanaman, Ternakan dan Perikanan. 2006. Projek Pertanian Moden Kluang. http://agrolink.moa.my/moa/index2.php?option=com content\&task=view\&id=156\&pop=... [2 November 2007].

[12] Kementerian Pertanian Malaysia. 1999. Dasar pertanian negara ketiga ( 1998-2010 ). Kuala Lumpur: Kementerian Pertanian Malaysia.

[13] Mohd Haikal Isa. 2005. Projek pertanian moden Bantu negara kurangkan import makanan. Jabatan Perkhidmatan Haiwan Malaysia Negeri Perak: Bernama 14 Februari. http://www.jphpk.gov.my/Malay/Feb05\%2014b.htm [2 November 2007].

[14] Mokhtar Tamin. 1981. Rice self-sufficiency in Malaysia: policy and reality. Dlm. H Osman Rani, Jomo K. S \& Ishak Shari (pnyt.). Development in the eighties with emphasis on Malaysia, hlm. 1-19. Bangi: Universiti Kebangsaan Malaysia.

[15] Mercedita A. Sombilla \& Mahabub Hossain. 2000. Rice and food security in Asia: a long term outlook. Dlm. Wen S. Chern, Collin A. Carter \& Shun-Yi Shei (pnyt.). Food security in Asia economics and policies, hlm. 35-60. UK: Edward Elgar Publishing, Inc.

[16] Pazim Othman. 1992. Land abandonment in the rice sector: an economic analysis. Jurnal Ekonomi Malaysia 26: 21 -45

[17] Roger D. Norton. 2004. Agricultural development policy concepts and experiences. England: John Wiley \& Sons, Ltd.

[18] Sivalingam G. 1993. Malaysia's agricultural transformation. Petaling Jaya: Pelanduk Publications.

[19] Tan Siew Hoey. 1986. Whither the case of food security in Malaysia. Seminar on Food Security and Policy Issues in Malaysia. Faculty of Economic and Management. Universiti Pertanian Malaysia. Serdang, 28-29 July.

[20] Zulkifli Hj Mustapha, Chamhuri Siwar \& Nik Hashim Nik Mustapha. 1986. Food economy of Malaysia problems and policies in food security. Bangi: Universiti Kebangsaan Malaysia. 